\title{
ЗМІНИ ВЕГЕТАТИВНОЇ РЕГУЛЯЦІЇ У ХВОРИХ НА СТАБІЛЬНУ СТЕНОКАРДІЮ ТА СУБКЛІНІЧНИЙ ГІПОТИРЕОЗ
}

\author{
А. В. Волобуєва, М. І. Швед, Л. П. Мартинюк, І. Б. Киричок \\ ТОВ «Медікап», м. Одеса \\ ДВНЗ «Тернопільський державний медичний університет \\ імені І. Я. Горбачевського мОЗ Украӥни»
}

\begin{abstract}
У пацієнтів із стабільною стенокардією у поєднанні з субклінічним гіпотиреозом часто виявляють дисбаланс вегетативної регуляції. В ході дослідження обстежено 44 пацієнти із стабільною стенокардією та збереженою або зниженою функцією щитоподібної залози. Вивчали параметри варіабельності ритму серця.

У хворих на стенокардію навантаження у поєднанні з субклінічним гіпотиреозом значення ТР становило $(2325,95 \pm 49,83)$ мс² $^{2}$ а симпатовагусний індекс зростав і становив $2,29 \pm 0,04$, що свідчить про зниження варіабельності ритму серця та гіперсимпатикотонію, тоді як у хворих на стенокардію навантаження зі збереженою функцією щитоподібної залози ці зміни були менш вираженими та становили, відповідно, $(3054,30 \pm 32,13) \mathrm{Mc}^{2}$ i $2,08 \pm 0,06$.
\end{abstract}

\section{VEGETATIVE REGULATION DISTURBANCES IN PATIENTS WITH ANGINA PECTORIS AND SUBCLINICAL HYPOTHYROIDISM}

\author{
A. V. Volobueva, M. I. Sved, L. P. Martynyuk, I. B. Kyrychok \\ LLC «Medikap», Odesa \\ I. Horbachevsky Ternopil State Medical University
}

\begin{abstract}
In patients with stable angina and subclinical hypothyroidism an imbalance of vegetative regulation can be often developed. 44 patients with stable angina and normal or reduced thyroid gland function were included in the study. The main aim of the study was heart rate variability assessment.

In patients with stable angina and subclinical hypothyroidism, TP was $(2325.95 \pm 49.83) \mathrm{ms}^{2}$, and the sympathovagal balance increased to $2.29 \pm 0.04$, indicating a decrease of heart rate variability and hypersympathicotonia. In patients with stable angina and normal function of the thyroid gland, these changes were less pronounced and amounted to $(3054.30 \pm 32.13) \mathrm{ms}^{2}$ and $2.08 \pm 0.06$ respectively.
\end{abstract}

Вступ. Протягом останніх десятиліть вітчизняними науковцями відзначено суттєве зростання патології щитоподібної залози (ЩЗ) на всій території України, особливо в областях із природньою нестачею йоду. Варто зауважити, що всі області Західної України належать до регіонів із тяжким дефіцитом йоду, що в майбутньому $\epsilon$ вагомим фактором ризику розвитку йододефіцитних захворювань (ЙД3) [2, 6]. Беззаперечним залишається той факт, що основною ланкою патогенезу Йдз є зниження функціональної активності щЗ і, як наслідок - розвиток широкого спектра патологічних станів, зокрема субклінічного гіпотиреозу $[1,3]$. На сьогодні у світі питання субклінічного гіпотиреозу, як досить поширеного патологічного стану, активно обговорюють в численних публікаціях і на наукових форумах. У пацієнтів із субклінічним гіпотиреозом спостерігають дисбаланс гормонів щз, який викликає порушення діяльності різних органів та систем, зокрема сприяє розвитку та прогресуванню серцево-судинної патології.

У 2017 р. в Україні відсоток хвороб системи кровообігу становив 55,1%. Питома вага ішемічної хвороби серця (IXC) серед жителів нашої країни становила 32,7 \% (2017 р.), а частка стенокардії сягає 11,5\% (8559,7 випадків на 100 тис. населення). При цьому, слід зауважити, що за період 2012-2017 рр. поширеність IXC, у тому числі й стабільної стенокардії серед дорослого населення, на відміну від країн Європи та США, зросла на 4,9% [5].

(․ А. В. Волобуєва, М. І. Швед, Л. П. Мартинюк, І. Б. Киричок, 2018

12 ISSN 2411-1597. МЕДСЕСТРИНСТВО. 2018. № 2 
Варто зауважити, що вплив нестачі гормонів щЗ при явному гіпотиреозі на зміни кардіальної патології досліджено досить широко, проте особливості патогенезу, клініки, діагностики та лікування субклінічної гіпофункції щЗ при наявності стабільної стенокардії вимагають більш ретельного вивчення [4]. В літературі не повною мірою висвітлено особливості змін вегетативної регуляції серця у пацієнтів із стабільною стенокардією при поєднанні з субклінічним гіпотиреозом.

Основна частина. Обстежено 44 хворих на IXC, стенокардію навантаження II-III функціонального класу (ФК). Стенокардію навантаження ІІ ФК діагностовано у 20 пацієнтів (45,5 \%), а III ФК - у 24 (54,5 \%). Середній вік обстежених становив $(52,4 \pm 1,7)$ року та коливався від 42 до 74 років. До контрольної групи увійшло 20 практично здорових осіб такого ж віку та статі. Усіх хворих поділено на дві групи. До першої групи увійшло 23 пацієнти (52,3 \%) хворих на стенокардію навантаження без проявів гіпофункції щитоподібної залози, до другої 21 (47,7 \%) із поєднанням стенокардії навантаження та субклінічного гіпотиреозу.

Із огляду на те, що у хворих на стенокардію навантаження і, особливо, при приєднанні гіпотиреозу порушується функціональний стан автономної вегетативної регуляції серцевої діяльності, що призводить до дисбалансу симпатичних і парасимпатичних впливів на серце й може суттєво впливати на перебіг як IXC, так і серцевої недостатності, нами обстежено обидві групи пацієнтів за допомогою холтерівського моніторування ЕКГ, апаратом CardioTens N2002/CT, серія 102198.

Із спектральних показників вивчали: TP; HF, що $\epsilon$ показником парасимпатичної активності; LF, що характеризує симпатопарасимпатичну модуляцію барорефлекторної природи; індекс LF/HF, що відображає симпатопарасимпатичний баланс.

Виявлено знижену загальну потужність спектра ТP на 41,4\% у пацієнтів із стенокардією навантаження та субклінічним гіпотиреозом порівняно з контрольною групою та зниження цього показника на 23,8 \% порівняно з хворими зі збереженою функцією щз (табл. 1).

Значення LFy хворих другої групи було достовірно нижчим на 42,0 \%, ніж у контрольній групі, та на 24,7 \% меншим, ніж у пацієнтів зі стенокардією навантаження зі збереженою функцією Щз. Компонента HF знижувалась ще більшою мірою. Так, у хворих на стенокардію навантаження та з субклінічним гіпотиреозом цей показник був меншим на 60,1% від значень у хворих контрольної групи та на 31,7 \% нижчим - зі збереженою функцією Щз. Це свідчить про суттєве послаблення парасимпатичних впливів на серце.

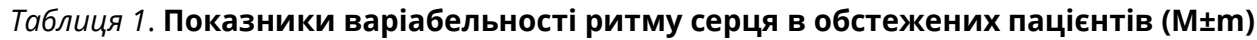

\begin{tabular}{|c|c|c|c|c|c|c|}
\hline Показник & $\begin{array}{c}\text { Контрольна група } \\
(n=20)\end{array}$ & $\begin{array}{c}\text { IХС зі збереженою } \\
\text { функцією щЗ }(n=23)\end{array}$ & $\begin{array}{c}\text { IХС із субклінічним } \\
\text { гіпотиреозом } \\
(n=21)\end{array}$ & $p_{1-2}$ & $p_{1-3}$ & $p_{2-3}$ \\
\hline TP & $3969,10 \pm 92,37$ & $3054,30 \pm 32,13$ & $2325,95 \pm 49,83$ & $<0,01$ & $<0,01$ & $<0,01$ \\
\hline LF & $1460,80 \pm 43,71$ & $1125,39 \pm 31,27$ & $847,57 \pm 29,85$ & $<0,01$ & $<0,01$ & $<0,01$ \\
\hline HF & $931,10 \pm 13,50$ & $544,04 \pm 9,37$ & $371,52 \pm 7,58$ & $<0,01$ & $<0,01$ & $<0,01$ \\
\hline LF/HF & $1,57 \pm 0,05$ & $2,08 \pm 0,06$ & $2,29 \pm 0,04$ & $<0,01$ & $<0,01$ & $<0,05$ \\
\hline
\end{tabular}

Примітки: $p_{1-2}$ - достовірність відмінності показників у пацієнтів зі збереженою функцією щЗ порівняно з контрольною групою; $p_{1-3}$ - достовірність відмінності показників у хворих із субклінічним гіпотиреозом порівняно з контрольною групою; $p_{2-3}-$ достовірність відмінності показників у пацієнтів із субклінічним гіпотиреозом порівняно зі збереженою функцією щз.

Симпатовагусний індекс (LF/HF) підвищувався, оскільки зниження HF відбувалось більшою мірою ніж LF. У хворих другої групи LF/HF був достовірно вищим (на 45,9\%), ніж у контрольній групі здорових осіб та на 10,1 \% вищим, ніж у пацієнтів зі стенокардією навантаження зі збереженою функцією щз, що свідчить про зростання гіперсимпатикотонії.

Варто відзначити, що вивчення змін варіабельності ритму серця у пацієнтів із стабільною стенокардією та субклінічним гіпотиреозом є досить важливим через те, що перебіг ІХC суттєво видозмінюється із переважанням гіперсимпатикотонії.
Висновки. 1.У всіх обстежених пацієнтів обох груп виявлено ознаки дисбалансу вегетативної регуляції серцевої діяльності.

2. У хворих на стенокардію навантаження в поєднанні зі субклінічним гіпотиреозом значення ТР досягало $(2415,70 \pm 37,31 /)$ мс리 $^{2}$ а симпатовагусний

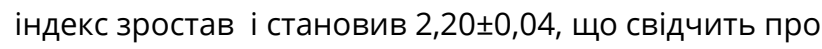
зниження варіабельності ритму серця та гіперсимпатикотонію. У хворих на стенокардію навантаження зі збереженою функцією щитоподібної залози ці зміни були менш вираженими й становили, відповідно,

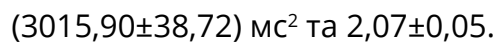




\section{СПИСОК ЛІТЕРАТУРИ}

1. Булдигіна Ю. В. Проблема йододефіциту: історія питання, шляхи вирішення / Ю.В.Булдигіна // Клінічна ендокринологія та ендокринна хірургія. - 2009. № 4 (29). - С. 9-14.

2. Жижин К. С. Аспекты купирования йоддефицитных состояний организма на фоне экологического дисбаланса / К. С. Жижин, Л. П. Нелина // Международный журнал прикладных и фундаментальных исследований. - 2011. № 8. - С. 20-22.

3. Заремба $Є$. Х. Субклінічний гіпотиреоз: лабораторний феномен чи окрема нозологія? / Є. Х. Заремба, І. С. Шатинська-Мицик // Сучасні препарати та технології. 2010. - № 4 (70). - С. 52-55.
4. Зелінська Н. Б. Клінічні прояви ураження серцево-судинної системи у хворих на гіпотиреоз / Н. Б. Зелінська // Клінічна ендокринологія та ендокринна хірургія. - 2008. № 2 (23). - С. 22-31.

5. Динаміка стану здоров'я народу України та регіональні особливості : аналітично-статистичний посібник / Національний науковий центр «Інститут кардіології імені академіка М. Д. Стражеска» НАМНУ. - К., 2017. - 215 с.

6. Стандарти надання медичної допомоги хворим 3 патологічними станами щитоподібної залози в умовах дії негативних чинників довкілля / за ред. О. В. Камінського. 2-ге вид. - К. : Старт-98, 2015. - 223 с.

Отримано 29.03.18 